\title{
Stability and In Vitro Dissolution Studies of Metronidazole Tablets and Infusions
}

\author{
Fadilah S. Aleanizy ${ }^{1,}{ }^{*}$, Huda Al-Eid ${ }^{2}$, Eram El Tahir ${ }^{1}$, Fulwah Alqahtani ${ }^{1}$, and Omaimah Al-Gohary ${ }^{1}$ \\ ${ }^{1}$ College of Pharmacy, Department of Pharmaceutics, King Saud University, Riyadh, Saudi Arabia \\ ${ }^{2}$ College of Pharmacy, Department of Pharmaceutics, Dammam University, Dammam, Saudi Arabia \\ e-mail:faleanizy@ksu.edu.sa
}

\begin{abstract}
The aim of this study was to compare metronidazole tablets $(500 \mathrm{mg})$ and infusions $(500 \mathrm{mg} / 100 \mathrm{~mL})$ obtained from Saudi and Egyptian suppliers. Evaluation of the tablets included weight variation, hardness, friability, drug content, disintegration time, and dissolution profiles. Stability of the tablets in their original packages after 3-month storage at various temperatures (75\% relative humidity) was evaluated, and degradation kinetics was determined. The infusion solutions underwent accelerated stability testing. The $Q_{10}$ method was used to estimate the shelf life of metronidazole infusions at room temperatures ( $75 \%$ relative humidity) of various climates. Results revealed that all tablets complied with USP specifications, and degradation was slowest at room temperature $\left(20^{\circ} \mathrm{C}\right)$. The mechanism of drug release for all tablets at all temperatures conformed to the Korsmeyer-Peppas model. Metronidazole intravenous infusion solutions stored at $40{ }^{\circ} \mathrm{C}$ or $50^{\circ} \mathrm{C}$ for 90 days exhibited good stability. The studied Saudi infusion brand is more stable than Egyptian one. The metronidazole tablets and infusion solutions complied with USP specifications and showed similar results in quality control testing. Standard quality control measures should be maintained to ensure safety and efficacy of drug products, especially in climates with extreme temperatures.
\end{abstract}

KEYWORDS: Metronidazole; Riazole; Amrizole; stability study; expiry date; infusion; quality control; dissolution.

\section{INTRODUCTION}

$\mathrm{M}$ etronidazole is classified as an antiamoebic, antigiardiasis, amoebicidal, antiprotozoal, and antibacterial drug in the World Health Organization's Essential Medicines List (1). Metronidazole is commonly used in combination with other antibiotics and either bismuth compounds or proton pump inhibitors to treat peptic ulcer disease caused by Helicobacter pylori. Metronidazole is also used to treat periodontal disease caused by Gardnerella vaginalis and infections caused by anaerobic bacteria including intra-abdominal infections, skin and skin structure infections, gynecological infections, bacterial septicemia, bone and joint infections, central nervous system infections, lower respiratory tract infections, and endocarditis (2-4). Metronidazole is rapidly absorbed, with a bioavailability approaching $100 \%$ $(5,6)$. The solubility of metronidazole in water at room temperature is $64.8 \mathrm{mg} / \mathrm{mL}$ at $\mathrm{pH} 1.2$ and approximately $10 \mathrm{mg} / \mathrm{mL}$ at $\mathrm{pH} 2.5-8.0$ (7).

The stability of a drug is a primary concern in climates with extreme temperatures. Previous studies $(8,9)$ have reported the stability and other quality control parameters of various brands of metronidazole tablets. In a study testing metronidazole tablets marketed in Zaria, Nigeria, only $60 \%$ of the tested metronidazole drugs passed the quality control test $(10,11)$. Another study testing the bioavailability of 10 brands of metronidazole tablets from different manufacturers reported wide variations in hardness, weight uniformity, friability, disintegration time, absolute drug content, and dissolution efficiency. Only some of the brands showed acceptable tablet characteristics. These results are clinically important because drugs are expected to conform to label claims and exhibit satisfactory bioavailability (12-14).

In this study, we evaluated the effect of temperature on the stability of two brands of metronidazole tablets and intravenous infusion solutions manufactured in Saudi Arabia and Egypt.

\section{METHODS AND MATERIALS \\ Materials}

Metronidazole tablets (Riazole $500 \mathrm{mg}$ and Amrizole 500 $\mathrm{mg}$ ) were kindly provided by Riyadh Pharma (Riyadh, Saudi Arabia) and Amriya Pharmaceutical Industries (Alexandria, Egypt), respectively. Metronidazole intravenous infusion solutions $(500 \mathrm{mg} / 100 \mathrm{~mL}$; sterile, nonpyrogenic) were kindly provided by Pharmaceutical

${ }^{*}$ Correspondence author 
Solution Industry (Jeddah, Saudi Arabia) and Amriya Pharmaceutical Industries (Alexandria, Egypt). Distilled water was used to reconstitute metronidazole.

\section{Storage of Metronidazole Tablets at Different Temperatures}

All of the tested samples were within their shelf life and expiry dates. The tablets were stored at different temperatures $\left(4,20\right.$, and $\left.40{ }^{\circ} \mathrm{C}\right)$ at $75 \%$ relative humidity $(\mathrm{RH})$ for 3 months and then tested as follows.

\section{Dissolution Test}

Dissolution testing was conducted according to USP 32 (15). Dissolution rates of metronidazole tablets were determined in $900 \mathrm{~mL}$ of $\mathrm{HCl}(0.1 \mathrm{M})$ at $37 \pm 0.5^{\circ} \mathrm{C}$ using an Erweka dissolution apparatus (Automated Dissolution Testing Apparatus Type I, Germany) at a rotational speed of $100 \mathrm{rpm}$. Triplicate samples $(5 \mathrm{~mL})$ were removed at 5-min intervals over 60 min and replaced immediately with an equal volume of $0.1 \mathrm{M} \mathrm{HCl}$ to maintain sink conditions. Three experimental runs were performed, and the results were averaged. The amount of metronidazole that dissolved over $60 \mathrm{~min}$ was determined by measuring absorbance at $277 \mathrm{~nm}$ using a UV-vis spectrophotometer (Spectro UV-VIS Auto Scanning UV-2602).

\section{Hardness Test (Crushing Strength)}

Tablet hardness was evaluated using an Erweka hardness tester. The average force required to break 10 randomly selected tablets of each metronidazole brand was calculated. USP 32 states that a crushing strength of 4-8 $\mathrm{kg}$ is acceptable for uncoated, non-sustained-release tablets.

\section{Disintegration Test}

Six tablets from each metronidazole batch were placed in the six tubes of the apparatus and immersed in distilled water at $37 \pm 0.5^{\circ} \mathrm{C}$. The time required for all six tablets to break into particles and pass into the disintegration medium was recorded. As specified by USP 32, if one tablet failed to disintegrate within $30 \mathrm{~min}$, the disintegration test was repeated on 12 additional tablets. Sixteen of the 18 tablets tested disintegrated completely within $30 \mathrm{~min}$.

\section{Drug Content Test}

All samples examined were within their shelf life and expiry dates. After storage at $4{ }^{\circ} \mathrm{C}$ (refrigerator), $20{ }^{\circ} \mathrm{C}$ (room temperature), or $40{ }^{\circ} \mathrm{C}$ (oven) at $75 \% \mathrm{RH}$ for 1 week, 1 month, 2 months, or 3 months, the tablets were subjected to a drug content test ( $n=3$ for each condition). One tablet was transferred to a $250-\mathrm{mL}$ volumetric flask with $100 \mathrm{~mL}$ diluted hydrochloric acid $(1: 100)$ and shaken for $30 \mathrm{~min}$, according to USP 32 specifications. The filtrate $(100 \mathrm{~mL})$ was transferred to a $100-\mathrm{mL}$ volumetric flask, diluted to volume with $0.1 \mathrm{M} \mathrm{HCl} \mathrm{pH} 1.2$ (1:100), and mixed to obtain a solution that was approximately $0.2 \mathrm{mg} / \mathrm{mL}$. The absorbance of this test solution and a standard solution of USP Metronidazole RS (approx. $20 \mu \mathrm{g} / \mathrm{mL}$ ) in a $1-\mathrm{cm}$ matched cell was determined concomitantly at $277 \mathrm{~nm}$ using a UV-vis spectrophotometer. Diluted hydrochloric acid (1:100) was used as a blank, and the mean of at least three absorbance readings was calculated. The quantity of metronidazole $(\mathrm{mg})$ in the tablets was calculated using the following equation:

$$
(T C / D)\left(A_{U} / A_{s}\right)
$$

where $T$ is the label quantity (mg), $C$ is the concentration $(\mu \mathrm{g} / \mathrm{mL})$ of USP Metronidazole RS in the standard solution, $D$ is the concentration $(\mu \mathrm{g} / \mathrm{mL})$ of the test solution, $A_{u}$ is the absorbance of the test solution, and $A_{s}$ is the absorbance of the standard solution. Acceptable values are $90-110 \%$ of the labeled amount.

\section{Stability of Metronidazole Intravenous Infusion Solutions}

The stability of the metronidazole intravenous infusion solutions was evaluated under accelerated storage conditions of $40{ }^{\circ} \mathrm{C}$ and $50{ }^{\circ} \mathrm{C}(75 \% \mathrm{RH})$ for $7,30,60$, and 90 days. The shelf life under recommended storage conditions may be estimated by storing the product under extreme conditions (e.g., temperature, humidity, light, and radiation). Temperature is the most common acceleration factor for chemical, pharmaceutical, and biological products because its relationship with the degradation rate is characterized by the Arrhenius equation (eq 2).

Shelf life was estimated using the $Q_{10}$ method, where $Q_{10}$ is the factor by which the rate constant increases for a $10{ }^{\circ} \mathrm{C}$ rise in temperature. The absorbance of the samples in $0.1 \mathrm{~N} \mathrm{HCl}$ was determined at $277 \mathrm{~nm}$ using a UV-vis spectrophotometer. Equation 17 describes the relationship between temperature and degradation rate, where $A$ is absorbance, $R$ is the rate, and $T$ is temperature $\left({ }^{\circ} \mathrm{C}\right)$.

$$
\left.k=A e^{(-E a / R T}\right)
$$

where $A$ is the pre-exponential factor, $E_{a}$ is activation energy, $R$ is the universal gas constant, and $T$ is temperature in degrees Kelvin.

$$
\log k=\log A-\left(E_{a} / 2.303 R T\right)
$$


For $k_{1}$ and $k_{2}$, we can rearrange in the following manner:

$$
\begin{array}{ll} 
& \log k_{2} / k_{1}=-E a / 2.303 R\left(1 / T_{2}-1 / T_{1}\right) \\
\text { or } & \log k_{2} / k_{1}=E a\left(T_{2}-T_{1}\right) / 2.303 R T_{2} T_{1} \\
& Q_{10}=e^{[-E a / R(1 / T+10-1 / T)]} \\
\text { or } & Q_{10}=e^{[E a .10 / R(T+10) T])}
\end{array}
$$

For an arbitrary temperature change $\Delta T$,

$$
Q_{\Delta T}=\mathrm{e}^{[E a \cdot \Delta T / R(T+\Delta T) T])}
$$

Multiplying the exponential term by $10(T+10) / 10(T+10)$, gives the following:

$$
\begin{array}{lll}
Q_{\Delta T} & =\mathrm{e}^{[E a / R\{\Delta T \cdot 10(T+10) /(T+\Delta T) T \cdot 10(T+10)\}]} \\
\text { or } & Q_{\Delta \mathrm{T}}=\mathrm{e}^{[E \sigma / R\{10 /(T+10) T \times \Delta T(T+10) /(T+\Delta T) 10\}} \\
\text { or } & Q_{\Delta \mathrm{T}}=\mathrm{e}^{\{E a / R\{10 /(T+10) T\}[\Delta T(T+10) /(T+\Delta T) 10]} \\
\text { or } & Q_{\Delta \mathrm{T}}=Q_{10}[(\Delta T / 10)(T+10) /(T+\Delta T)] \\
& T \equiv 300 K,(T+10) /(T+\Delta T) \equiv 1
\end{array}
$$

(For a $10-20^{\circ} \mathrm{C}$ interval, it is almost equal to 1. )

Therefore, $\quad Q_{\Delta T}=k_{T}+\Delta T / k_{T}=Q_{10} \Delta T / 10$

In this way, for a $10-20^{\circ} \mathrm{C}$ interval,

$$
Q_{\Delta T}=Q_{10}{ }^{\Delta T / 10}
$$

To evaluate the effect of temperature on shelf life, we can correlate the $Q_{\Delta T}$ value with shelf life. Degradation reactions generally follow zero-order, first-order, or pseudo-first-order kinetics. The shelf life in these cases is:

$$
t_{90}=0.1\left[D_{0}\right] / k_{0}
$$

where the degradation process is zero-order, and $D_{0}$ is the initial concentration,

$$
t_{90}=0.105 / k_{1}
$$

where the reaction is a first-order process and $0.1, D_{0}$, and 0.105 are the constants.

Therefore, shelf life can be written as $t_{90}=a / k T$.

For $T_{1}$ and $T_{2}$,

$t_{90}\left(T_{1}\right)=a / k T_{1}$ and $t_{90}\left(T_{2}\right)=a / k T_{2}$

Since, $T_{2}=T_{1}+\Delta T$,

$$
t_{90}\left(T_{2}\right)=a / k\left(T_{1}+\Delta T\right)
$$

Using $k_{(T+\Delta T)} / k_{T}=Q_{10} \Delta T / 10$ of eq 16 in the above equation, we get

$$
t_{90}\left(T_{2}\right)=a /\left(k T_{1} \cdot Q_{10} \Delta T / 10\right)
$$

Because $t_{90}\left(T_{1}\right)=a / k T_{1}$ :

$$
t_{90}\left(T_{2}\right)=t_{90}\left(T_{1}\right) / Q_{10} \Delta T / 10
$$

The $Q_{10}$ equation (eq 17) is independent of the order of reaction. $Q_{10}$ has low, average, and high estimate values $(2,3$, and 4 , respectively). A zero- or first-order kinetics reaction occurs at elevated temperatures and at the recommended storage temperature. The same model was used to fit the degradation patterns at each temperature.

\section{Kinetics Study}

The in vitro release mechanisms of the drug in tablets and infusions were evaluated using four kinetic models (Table 1).

Table 1: Kinetic Models Used for the Analysis of Metronidazole Release

\begin{tabular}{|c|c|c|}
\hline No. & Model name & Model \\
\hline 1 & Zero order & $Q_{t}=Q_{0}+K_{0} t$ \\
\hline 2 & First order & $\begin{array}{c}\log Q_{t}=\log Q_{0}+K_{1} t \\
/ 2.303\end{array}$ \\
\hline 3 & Higuchi & $Q=K_{H} t^{1 / 2}$ \\
\hline 4 & Korsmeyer-Peppas & $M_{t} / M_{\infty}=K t^{n}$ \\
\hline
\end{tabular}

Model parameters were obtained by linear regression. $Q$ and $M$ denote fraction of drug released up to time $t, K$ is the rate constant, and $n$ is the release exponent.

\section{Statistical Analysis}

Stability of the intravenous infusion solutions over time was analyzed using regression analysis.

\section{RESULTS AND DISSCUSION}

\section{Characterization of Metronidazole Tablets}

Figure 1 shows dissolution profiles of the $500-\mathrm{mg}$ metronidazole tablets, demonstrating that dissolution was within USP limits (i.e., not less than $85 \%$ of the labeled amount of metronidazole dissolved in $60 \mathrm{~min}$ ). However, dissolution fluctuated in tablets that were stored at $40^{\circ} \mathrm{C}$, because the dissolution medium $\mathrm{pH}$ was 1.5 .

Table 2 shows the remaining drug (log percent) over time in tablets stored at $4{ }^{\circ} \mathrm{C}, 20^{\circ} \mathrm{C}$, or $40{ }^{\circ} \mathrm{C}(75 \% \mathrm{RH})$ for 3 months. The highest concentration of metronidazole in the tested tablets was $482 \mathrm{mg}$ per tablet after storage at $20{ }^{\circ} \mathrm{C}$ for 7 days, and the lowest concentration was $339 \mathrm{mg}$ per tablet after storage at $40{ }^{\circ} \mathrm{C}$ for 90 days. The drug content was highest when the tablets were stored 


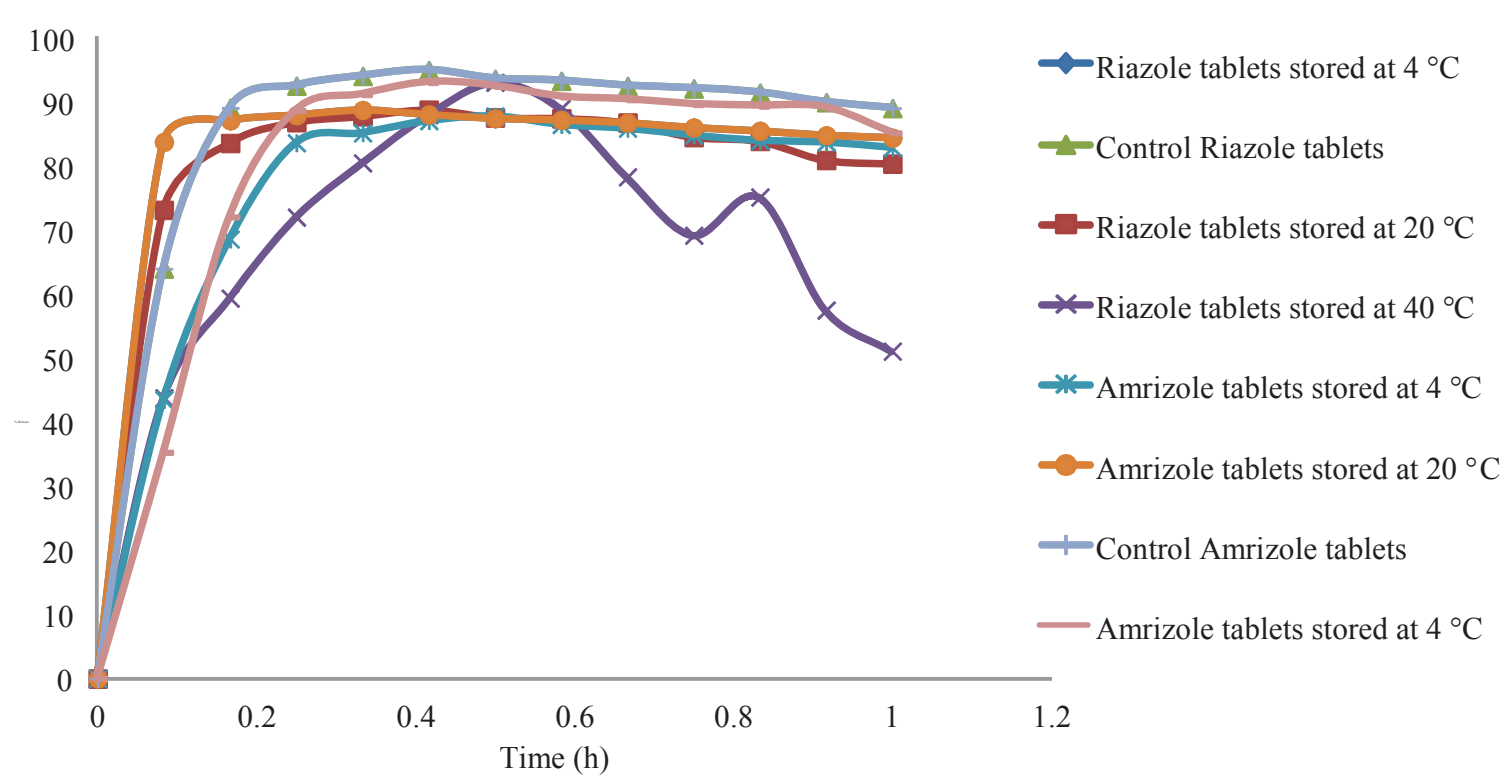

Figure 1. Dissolution profile of Riazole and Amrizole tablets after storage at $4{ }^{\circ} \mathrm{C}, 20^{\circ} \mathrm{C}$, or $40^{\circ} \mathrm{C}$ and $75 \%$ RH for 3 months $(n=3)$.

Table 2. Drug Content of Two Brands of Metronidazole Tablets Stored at Accelerated Conditions ${ }^{a}$ for Three Months

\begin{tabular}{|c|c|c|c|c|c|c|c|c|c|c|c|c|c|c|}
\hline \multicolumn{15}{|c|}{ Drug remaining (\%) } \\
\hline & \multicolumn{2}{|c|}{7 days } & \multicolumn{2}{|c|}{15 days } & \multicolumn{2}{|c|}{30 days } & \multicolumn{2}{|c|}{45 days } & \multicolumn{2}{|c|}{60 days } & \multicolumn{2}{|c|}{75 days } & \multicolumn{2}{|c|}{90 days } \\
\hline Temp. $\left({ }^{\circ} \mathrm{C}\right)$ & $\mathrm{s}$ & $\mathrm{E}$ & $\mathrm{s}$ & $\mathrm{E}$ & $\mathrm{s}$ & $\mathrm{E}$ & $\mathrm{s}$ & $\mathrm{E}$ & $\mathrm{s}$ & $E$ & $\mathrm{~s}$ & $\mathrm{E}$ & $\mathrm{s}$ & $\mathrm{E}$ \\
\hline 4 & 89 & 94.24 & 88 & 94.24 & 87 & 94.11 & 86.8 & 93.72 & 86 & 86.27 & 84 & 81.96 & 81 & 73.72 \\
\hline 20 & 90 & 96.33 & 89 & 95.94 & 88 & 95.55 & 86 & 93.85 & 85 & 91.50 & 83 & 81.96 & 82 & 73.72 \\
\hline 40 & 92 & 95.81 & 92 & 94.24 & 92 & 92.81 & 86 & 92.41 & 81 & 89.52 & 79 & 78.69 & 77 & 67.84 \\
\hline
\end{tabular}

${ }^{a} 4,20$, or $40^{\circ} \mathrm{C}$ and $75 \% \mathrm{RH}$

$\mathrm{S}=$ Riazole 500-mg tablet (manufactured in Saudi Arabia).

$\mathrm{E}=$ Amrizole 500-mg tablet (manufactured in Egypt).

Table 3. Testing Results and Estimated $n$ Values ${ }^{a}$ for Two Brands of Metronidazole Tablets Stored at 4, 20, or $40{ }^{\circ} \mathrm{C}(75 \% \mathrm{RH})$

\begin{tabular}{|c|c|c|c|c|c|c|c|c|c|c|c|c|}
\hline \multirow[t]{2}{*}{ Sample } & \multicolumn{2}{|c|}{ k (per day) } & \multicolumn{2}{|c|}{ \% Remaining } & \multicolumn{2}{|c|}{$\begin{array}{l}\text { Half-life } \\
\text { (days) }\end{array}$} & \multicolumn{2}{|c|}{$\begin{array}{l}\text { Mean disintegration } \\
\text { (min) }\end{array}$} & \multicolumn{2}{|c|}{ Mean hardness (kg) } & \multicolumn{2}{|c|}{$\begin{array}{l}\text { Estimated } \\
\mathrm{n} \text { value }\end{array}$} \\
\hline & S & E & S & $\mathbf{E}$ & S & $\mathbf{E}$ & S & E & S & E & S & $\mathbf{E}$ \\
\hline Control & - & - & - & - & - & - & 3.2 & 3 & 12.9 & 12.5 & 0.0206 & 0.0199 \\
\hline $4^{\circ} \mathrm{C}$ & 0.0003 & 0.00088 & 89 & 94.24 & 947.091 & 343.501 & 4.6 & 3.7 & 15 & 14.2 & 0.0031 & 0.0030 \\
\hline $20^{\circ} \mathrm{C}$ & 0.0005 & 0.00089 & 90 & 96.33 & 599.684 & 342.760 & 3.7 & 3 & 13 & 12.2 & 0.0269 & 0.0257 \\
\hline $40^{\circ} \mathrm{C}$ & 0.0014 & 0.00103 & 92 & 95.81 & 275.700 & 293.119 & 2.5 & 2.7 & 10.9 & 11.9 & 0.1048 & 0.1026 \\
\hline
\end{tabular}

5 = Riazole 500-mg tablet (manufactured in Saudi Arabia).

$\mathrm{E}=$ Amrizole 500-mg tablet (manufactured in Egypt).

${ }^{a}$ according to the Korsmeyer-Peppas equation

at room temperature. As shown in Table 3, the hardness values of the tablets exceeded $4-8 \mathrm{~kg}$, meeting USP 32 specifications. Tablets stored at $4{ }^{\circ} \mathrm{C}$ had the highest hardness values $(>14 \mathrm{~kg})$. Disintegration times were longest for tablets stored at $4{ }^{\circ} \mathrm{C}(4.6$ and $3.7 \mathrm{~min}$ for Amrizole and Riazole $500 \mathrm{mg}$, respectively) and shortest for tablets stored at $40^{\circ} \mathrm{C} \mathrm{(2.5} \mathrm{and} 2.7 \mathrm{~min}$ for Amrizole and Riazole $500 \mathrm{mg}$, respectively).

\section{Kinetic Modeling of Metronidazole Release from Tablets}

We tested zero-order, first-order, Higuchi, and KorsmeyerPeppas kinetics models of metronidazole release from tablets using dissolution data and release data. The bestfit model with the highest correlation coefficient $\left(R^{2}\right)$ was the Korsmeyer-Peppas model. The $n$ values for all metronidazole tablets (stored at $4{ }^{\circ} \mathrm{C}, 20^{\circ} \mathrm{C}$, or $40{ }^{\circ} \mathrm{C}$ for 
3 months) were less than 0.45 , which indicates that the drug release mechanism was Fickian diffusion (i.e., net flux from regions of high concentration to regions of low concentration).

In the present study, dissolution tests of Riazole and Amrizole tablets met USP requirements at all storage temperatures $\left(4{ }^{\circ} \mathrm{C}, 20^{\circ} \mathrm{C}\right.$, and $\left.40{ }^{\circ} \mathrm{C}, 75 \% \mathrm{RH}\right)$ with few differences, indicating that metronidazole tablets are stable over a wide temperature range. However, the ideal storage temperature is $20^{\circ} \mathrm{C}$, and the tablets should not be stored in the refrigerator. These results are in accordance with the results of previous studies $(9,16)$.

\section{Degradation Kinetics of Metronidazole Infusion Solution}

In addition, the stability of Egyptian and Saudi metronidazole infusions $(500 \mathrm{mg} / 100 \mathrm{~mL})$ was studied at 37 and $50{ }^{\circ} \mathrm{C}(75 \% \mathrm{RH})$ over $7,30,60$, and 90 days. The linear relationship between the logarithm of percent drug remaining and time indicates that degradation of metronidazole infusion solution follows pseudo-firstorder kinetics (Figure 2).

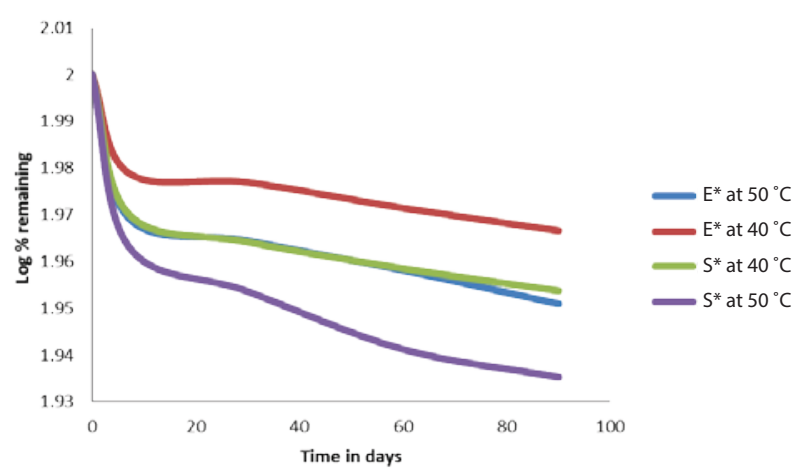

Figure 2. Pseudo-first-order degradation kinetics of metronidazole infusion solutions (S) manufactured in Saudi Arabia and (E) manufactured in Egypt stored at $40^{\circ} \mathrm{C}$ or $50^{\circ} \mathrm{C}$.

\section{Effect of Temperature on Shelf Life of Metronidazole Intravenous Infusion Solution}

The effect of higher temperatures on the degradation of the two metronidazole intravenous infusion solutions was evaluated; degradation was more rapid at $50^{\circ} \mathrm{C}$ than at $40^{\circ} \mathrm{C}$ (Table 4). The shelf life at $40^{\circ} \mathrm{C}$ was estimated at 1.9 years based on the rate constant at this temperature from eq 14 , and the shelf life at $25{ }^{\circ} \mathrm{C}$ was calculated using eq 17. There are three estimates for shelf life at $25{ }^{\circ} \mathrm{C}$ because $Q_{10}$ has three values to represent low, average, and high estimates. However, the activation energy indicated a lower estimate value. Using the $Q_{10}$ value of 2 in eq 17, expiry dates for the Saudi brand (usually 6 months shorter than shelf life) were estimated at 4.15 years at $25^{\circ} \mathrm{C}, 5.8$ years at $20^{\circ} \mathrm{C}$, and 2.4 years at $33{ }^{\circ} \mathrm{C}$, while the Egyptian brand showed different expiry dates that were 3.4 years at $25^{\circ} \mathrm{C}, 4.8$ years at 20 ${ }^{\circ} \mathrm{C}$, and 1.9 years at $33{ }^{\circ} \mathrm{C}$, where these represent room temperatures in the Asian subcontinent, winter zone, and tropical zone, respectively. Metronidazole intravenous infusion solutions stored at $40{ }^{\circ} \mathrm{C}$ or $50{ }^{\circ} \mathrm{C}$ over 90 days exhibited good stability. The rate constant values (Table 4) were used in modified Arrhenius equations to identify activation energy $\left(E_{a}\right)$, which was $8.7 \mathrm{kcal} / \mathrm{mole}$ for this preparation throughout the accelerated stability studies. The infusion solution was clear, and the $\mathrm{pH}$ was within the USP range at $40^{\circ} \mathrm{C}(6.11,6.10,6.11,6.12$, and 6.13$)$ and 50 ${ }^{\circ} \mathrm{C}(6.11,6.10,6.08,6.09$, and 6.1) for $0,7,30,60$, and 90 days, respectively.

The degradation rate constants of the Saudi brand, determined from the slopes of the plots, were $19.5289 \times$ $10^{-5}$ day $^{s-1}$ and $34.5217 \times 10^{-5}$ days $^{-1}$ for $40{ }^{\circ} \mathrm{C}$ and $50{ }^{\circ} \mathrm{C}$, respectively. The Egyptian brand showed rate constants of $28.194 \times 10-5$ day-1and $41.225 \times 10-5$ day- 1 for 40 ${ }^{\circ} \mathrm{C}$ and $50{ }^{\circ} \mathrm{C}$, respectively, and the $R^{2}$ values of both regression lines were approximately 1 .

Metronidazole intravenous infusion solution $(500 \mathrm{mg} / 100$ $\mathrm{mL}$ ) exhibited good stability when stored at $40^{\circ} \mathrm{C}$ or $50^{\circ} \mathrm{C}$ (75\% RH) for up to 90 days. Degradation followed pseudofirst-order kinetics. A previous study (11) reported degradation rate constants of $14.1604 \times 10^{-5}$ and $30.1 \times$ 105 day $^{-1}$ for $40^{\circ} \mathrm{C}$ and $50^{\circ} \mathrm{C}$, respectively.

\section{CONCLUSION}

The four commercially available metronidazole products manufactured in the Middle East were physically and chemically equivalent with few exceptions. The quality control methods used in this study are useful for monitoring batch-to-batch consistency of drug release. The therapeutic equivalence of the drugs must also be investigated by comparing their dissolution profiles.

\section{ACKNOWLEDGMENTS}

The authors thank Riyadh Pharma for their generous gift of metronidazole powder and tablets. The authors are grateful to the Research Centre of Science and Medical Studies Departments at King Saud University for their financial support.

\section{CONFLICT OF INTEREST}

The authors report no conflict of interest. 
Table 4. Results of Accelerated Stability Tests and Calculated Half-Life of Metronidazole Intravenous Infusion Solution (100 mL) Stored at $40^{\circ} \mathrm{C}$ and $50^{\circ} \mathrm{C}$

\begin{tabular}{|c|c|c|c|c|c|c|c|}
\hline \multirow{2}{*}{\multicolumn{2}{|c|}{ Time }} & \multicolumn{3}{|c|}{$50^{\circ} \mathrm{C}$} & \multicolumn{3}{|c|}{$40^{\circ} \mathrm{C}$} \\
\hline & & Drug \% mean & Conc. Mean & Abs. Mean & Drug \% mean & Conc. mean & Abs. Mean \\
\hline \multirow{2}{*}{ Control } & s & 0.674 & 500 & 100 & 0.674 & 500 & 100 \\
\hline & $\mathrm{E}$ & 0.674 & 500 & 100 & 0.674 & 500 & 100 \\
\hline \multirow{2}{*}{7 days } & S & 0.629 & 466.864 & 93.372 & 0.6193 & 459.446 & 91.880 \\
\hline & $\mathrm{E}$ & 0.642 & 476.261 & 95.252 & 0.628 & 465.875 & 93.175 \\
\hline \multirow{2}{*}{30 days } & S & 0.620 & 460.435 & 92.087 & 0.605 & 449.307 & 89.861 \\
\hline & $\mathrm{E}$ & 0.639 & 474.035 & 94.807 & 0.621 & 460.682 & 92.136 \\
\hline \multirow{2}{*}{60 days } & S & 0.612 & 454.500 & 90.901 & 0.588 & 436.696 & 87.339 \\
\hline & $E$ & 0.631 & 468.101 & 93.620 & 0.612 & 454.006 & 90.801 \\
\hline \multirow{2}{*}{90 days } & S & 0.606 & 449.555 & 89.911 & 0.580 & 430.761 & 86.152 \\
\hline & $E$ & 0.624 & 462.908 & 92.581 & 0.602 & 446.587 & 89.317 \\
\hline & & \multicolumn{3}{|c|}{$50^{\circ} \mathrm{C}$} & \multicolumn{3}{|c|}{$40^{\circ} \mathrm{C}$} \\
\hline \multirow{2}{*}{ K } & $\mathrm{s}$ & \multicolumn{3}{|c|}{$19.5 \times 10^{-5}$ days $^{-1}$} & \multicolumn{3}{|c|}{$34.5 \times 10^{-5}$ days $^{-1}$} \\
\hline & $\mathrm{E}$ & \multicolumn{3}{|c|}{$28.2 \times 10^{-5}$ days $^{-1}$} & \multicolumn{3}{|c|}{$41.23 \times 1^{0-5}$ days $^{-1}$} \\
\hline \multirow{2}{*}{$t_{90}$} & S & \multicolumn{3}{|c|}{$1.0203 y$} & \multicolumn{3}{|c|}{$0.833 y$} \\
\hline & $\mathrm{E}$ & \multicolumn{3}{|c|}{$1.47365 \mathrm{y}$} & \multicolumn{3}{|c|}{$0.697 y$} \\
\hline
\end{tabular}

$S=$ Riazole 500-mg tablet (manufactured in Saudi Arabia).

$E=$ Amrizole 500-mg tablet (manufactured in Egypt).

\section{REFERENCES}

1. WHO Model List of Essential Medicines, 16th ed.; World Health Organization: Geneva, Switzerland, 2009. http://apps.who.int/ iris/bitstream/10665/70642/1/a95055_eng.pdf (accessed Mar 8, 2017).

2. Robinson, S.; Meeks, T. W.; Geniza, C. Which Agents Work Best: FDA Approved and Off-Label Medications Help Patients Achieve Abstinence and Maintain Sobriety. Curr. Psychiatry 2014, 13 (1), 22-32.

3. Wenisch, C.; Parschalk, B.; Hasenhündl, M.; Hirschl, A. M.; Graninger, W. Comparison of Vancomycin, Teicoplanin, Metronidazole, and Fusidic Acid for the Treatment of Clostridium difficile-Associated Diarrhea. Clin. Infect. Dis. 1996, 22 (5), 813818. DOI: 10.1093/clinids/22.5.813.

4. Zar, F. A.; Bakkanagari, S. R.; Moorthi, K. M. L. S. T.; Davis, M. B. A Comparison of Vancomycin and Metronidazole for the Treatment of Clostridium difficile-Associated Diarrhea, Stratified by Disease Severity. Clin. Infect. Dis. 2007, 45 (3), 302-307. DOI: 10.1086/519265.

5. Lamp, K. C.; Freeman, C. D.; Klutman, N. E.; Lacy, M. K. Pharmacokinetics and Pharmacodynamics of the Nitroimidazole Antimicrobials. Clin. Pharmacokinet. 1999, 36 (5), 353-373. DOI: 10.2165/00003088-199936050-00004.

6. Remington: The Science and Practice of Pharmacy, 21st ed.; Remington, J. P., Troy, D. B., Beringer, P., Eds.; Lippincott Williams \& Wilkins: Philadelphia, 2006.

7. Lachman, L.; Lieberman, H. A.; Kanig, J. L. The Theory and Practice of Industrial Pharmacy, 3rd ed.; Lea \& Febiger: Philadelphia, 1986.
8. Musa, H.; Sule, Y.Z.; Gwarzo, M.S. Assessment of physicochemical properties of metronidazole tablets marketed in Zaria, Nigeria. Int. J. Pharm. Pharm. Sci. 2011, 3 (Suppl. 3), 27-29.

9. $\mathrm{Wu}, \mathrm{Y}$.; Fassihi, R. Stability of metronidazole, tetracycline $\mathrm{HCl}$ and famotidine alone and in combination. Int. J. Pharm. 2005, 290 (1-2), 1-13. DOI: 10.1016/j.jpharm.2004.10.015.

10. Ibezim, E. C.; Attama, A. A.; Obitte, N. C.; Onyishi, I.; Brown, S. A. In vitro prediction of in vivo bioavailability and bioequivalence of brands of metronidazole tablets in Eastern Nigerian drug market. Sci. Res. Essays 2008, 3 (11), 552-558. DOI: 1992-2248.

11. Shaheen, S. M. Accelerated Stability Study of Metronidazole Infusion 100 ml. J. Teach. Assoc. 2005, 18 (2), 118-121.

12. Gad, S. C. Drug Safety Evaluation, 2nd ed.; John Wiley \& Sons: New York, 2009.

13. Derendorf, H.; Lesko, L. J.; Chaikin, P.; Colburn, W. A.; Lee, P.; Miller, R.; Powell, R.; Rhodes, G.; Stanski, D.; Venitz, J. Pharmacokinetic/Pharmacodynamic Modeling in Drug Research and Development. J. Clin. Pharmacol. 2000, 40 (12), 1399-1418. DOI: 10.1177/009127000004001211.

14. Lockwood, G. B. The quality of commercially available nutraceutical supplements and food sources. J. Pharm. Pharmacol. 2011, 63 (1), 3-10. DOI: 10.1111/j.20427158.2010.01159.x.

15. The United States Pharmacopeia and National Formulary USP 32-NF 27; The United States Pharmacopeial Convention, Inc.: Rockville, MD, 2009.

16. Modern Pharmaceutics, 4th ed.; Banker, G. S.; Siepmann, J.; Rhodes, C., Eds.; Drugs and the Pharmaceutical Sciences, Vol.121; CRC Press: Boca Raton, FL, 2002. 